\title{
A REVIEW OF CYBER ETHNOGRAPHIC RESEARCH: A RESEARCH TECHNIQUE TO ANALYZE VIRTUAL CONSUMER COMMUNITIES
}

\author{
ULUN AKTURAN \\ Galatasaray University
}

\begin{abstract}
The purpose of this paper is to discuss the cyber ethnography-also called netnography-as a research tool in understanding and developing insights about virtual consumer communities. First of all, the "community," "virtual community," and the "virtual consumer communities" concepts are described. Following them, cyber ethnographic research is examined and the process of a cyber ethnographic research is discussed in details. In this section several research articles using cyber ethnographic method are presented in order to illustrate the research process and to develop a common point of view. In the conclusion, the pros and cons of cyber ethnographic research are discussed.
\end{abstract}

Key words: cyber ethnographic research, virtual communities, virtual consumer behavior, marketing research.

\section{SIBER ETNOGRAFIK ARAŞTIRMAYA ILISSKINN BIR INCELEME: SANAL TÜKETICI TOPLULUKLARINI INCELEMEK IÇİN BİR ARAŞTIRMA TEKNIĞĠ}

\begin{abstract}
ÖZET
Bu çalışmanın amacı, -netnografik araştırma olarak da adlandırılan- siber etnografik araştırmayı sanal tüketici topluluklarını anlamak ve kavramak için bir araştırma tekniği olarak tartışmaktır. Bu bă̆lamda, makalede öncelikle "topluluk," "sanal topluluk" ve "sanal tüketici topluluklarl" kavramları tanımlanmıştır. Daha sonra, siber etnografik araştırma incelenmiş ve siber etnografik araştırma süreci detaylı olarak ele alınmıştır. Bu aşamada, araştırma sürecini açılamak ve genel bir bakış açısı sağlamak amacıyla, siber etnografik teknik kullanılarak yapılmıs araştırma çalışmaları incelenmiştir. Sonuç olarak, siber etnografik araştırmanın avantaj ve dezavantajları tartışılmıştır.
\end{abstract}

Anahtar kelimeler: siber etnografik araştırma, sanal topluluklar, sanal tüketici toplulukları, pazarlama araştırmaları.

The internet has allowed people to form "webs of personal relationships" by connecting extremely diverse and dispersed populations. Computer networks, acting as social networks, are becoming important sites for new sorts of communities and communicative practices (Catterall and Maclaran, 2001: 228). The "connection" with an estimated number of 4000 new users per hour, has an accelerated

* Ulun Akturan is an Assistant Professor in the Department of Management at Galatasaray University, Çirağan Caddesi, No: 36, 34357, Ortaköy, Istanbul, Turkey. E-mail: uakturan@yahoo.com 
growth (Talukder and Yeow, 2006). Today, social interaction has a "virtual" version and cyberspace has evolved into a social place (Evans, et al., 2001). All over the world, lots of people have a virtual existence as well as their physical existence, and they participate in some form of virtual community.

Virtual communities are described as online social networks in which people with common interests, goals or practices share information and knowledge, and engage in social interactions (Chiu, Hsu and Wang, 2006). The virtual communities are important for marketers. This is because, first of all, these communities have a "real" existence and thus they have significant effects on many aspects of behavior, including consumer behavior (Kozinets, 1998; Muniz and O'Guinn, 2001). Secondly, the virtual communities have their norms, rules and value systems and so they have their own cultural composition and the unique collective senses which members share (Catterall and Maclaran, 2001). The participants of the virtual communities share their knowledge, opinions, and problems which generate experiences. They act as a community but have different characteristics from the real life community in terms of distance and communication. Moreover, in virtual communities which are explicitly structured around consumption activities, instead of simple browsing and buying, online experiences conducive to shopping are created (Kim and Jin, 2006). Therefore, understanding their behavioral patterns and profiling their decision-making styles will provide useful information for both academicians and practitioners.

Cyber ethnographic research is a helpful research tool for gaining knowledge about virtual communities. It provides a more accurate description of a virtual community (Ward, 1999). Since virtual communities form a specific culture and society, much more knowledge and interpretive insight can be gathered by cyber ethnographic research than any other research technique. That is because in conducting cyber ethnographic research, the researchers become a participant in the society and make observations as outsiders. Such knowledge provides information which can be used to influence members' choices, and to rapidly disseminate perceptions regarding new ideas, experiences, products, and services.

Cyber ethnographic research is a widely used technique in the virtual era although the applications may vary in terms of stages. The major concern of this study is to examine the concept of the virtual community and the process of the cyber ethnographic research. In addition, advantages and disadvantages of cyber ethnographic research are discussed by critically examining various studies of interest in the literature.

\section{THE VIRTUAL COMMUNITY CONCEPT}

Individuals belong to many communities in varying ways and are bounded to different extents (Wilson and Peterson, 2002). In this study, community as an entity is perceived as:

... emerging from the mutual commitment, mutual involvement, mutual responsibility and mutual respect between a society and its individual members (Walls 1993: 156). 
In a community, self identity and the group identity are in a reflexive relationship. That is, "a person is a person, is a personality because he belongs to a community" (Mead, 1993: 158). Karp et al. (1977) argue that the community should consist of three main elements: sustained social interaction, shared attributes and values, and a delineated geographic space (Talukder and Yeow, 2006). But today there are no geographical territories in relation to the networked computers. In other words, today there is no need for a shared territory in order for new communities to be formed. Instead, a common interest is enough. That is, the spirit of community is more important than the sense of place (Ward, 1999). Therefore these three elements were redefined by Lawrence (1995) as sustained social interaction, community standards, and membership rules (Talukder and Yeow, 2006).

The first virtual community appeared in the 1970s. But the growth of virtual communities was accelerated by the development of the World Wide Web (WWW) in the 1990s (Flavian and Guinaliu, 2005). They are formed in virtual environments accessed with internet tools and are not bound by time and space (Wellman, 2005). In the literature, virtual communities are defined in various ways. Rheingold (1994: 20) described the virtual community as:

... social aggregations that emerge from the net; enough people carry on those public discussions long enough, with sufficient human feeling, to form webs of personal relationships in cyberspace.

Kardaras et al. (2003: 41-42), define it as:

... a group of individuals who use electronic means such as the internet to communicate and share interests without the need to be in the same place, have physical contact or belong to the same ethnic group.

In contrast, Wilbur (1997: 14) uses a more contested definition:

Virtual community is the illusion of community where there are no real people and no real communication. It is a term used by idealistic technophiles who fail to understand that authentic cannot be endangered through technological means. Virtual community flies in the face of "human nature;" that is, essentially, it seems, depraved.

But in the literature it is generally accepted that the virtual communities have a physical existence as well as their virtual existence. It is determined that the virtual communities are perceived as "real" by the people who participated in them (Ward, 1999; Evans et al., 2001). Ward (1999) determined two major components of virtual communities. These are the fragility of the social group and its physical existence. Virtual communities are fragile social groups mainly because the members' commitment is an instrumental approach. Second, virtual communities are not entirely "virtual." The members have a physical existence in a physical world and the virtual communities cannot be isolated from this physical world. Rheingold (1994) reported that people in virtual communities are human beings but in the cyberspace they left their bodies behind. The components of virtual communities are "(1) a 
computer-mediated space that has no barriers like geographic boundaries, (2) interpersonal interaction, (3) content of discussion created by participants, and (4) a forum for public discussion where a sense of community are [sic] built." (Lee et al., 2003: 50)

Virtual communities allow people to exchange information, learn from each other, and meet their needs (Talukder and Yeow, 2006). These entities mainly satisfy four types of needs of their members; interest, relationship building, transaction, and fantasy (Armstrong and Hagel, 1997).

In sum, virtual communities can be defined as thus:

Virtual communities are relationship communities constituted in a computer-mediated space as fragile social and information networks in order to allow participants to interact with each other, to fulfill the needs of transaction and/or fantasy, and to share information, emotion and experience. It is thought that as the cyberspace evolves day by day, not only in terms of new users but also new needs and wants, the virtual communities will also emerge in relation to these developments. Currently, the virtual communities include chat rooms, boards, rings, lists, dungeons and social networks like Facebook. com, MySpace and Second Life.

In the literature virtual communities were classified on the basis of their structure, initiation, and content (Talukder and Yeow, 2006).

1. Classifications made on the basis of their structure: (1) Boards: electronic bulletin boards like usenet and newsgroups; (2) Rings: thematically linked web pages; (3) Lists: e-mail lists united by a common interest; (4) Dungeons: themed virtual locations in which interactions are structured by role playing rules; and (5) Chat rooms: unthemed virtual locations organized around common interests (Kozinets, 2002).

2. Classification made on the basis of their initiation: The virtual communities can be also classified on the bases of their initiation (Talukder and Yeow, 2006): (1) Virtual communities can be initiated by a company in order to provide easier company-to-customer relationship (Catterall and Maclaran, 2001; Ward, 1999; Alper, 1998; Chase, 1998). (2) Virtual communities can be formed independently by customers. These kinds of virtual communities have threats as well as opportunities for marketers.

3. Classifications made on the basis of their content: (1) Virtual communities based on specific interest topics (e.g. games, cosmetic surgery, online support groups); and (2) Virtual communities based on demographics, such as age (teens, 20s, 30s), gender, or ethnicity. These virtual communities provide the opportunity for study on specific consumer groups (Catterall and Maclaran, 2001).

In a sense, these classifications provide a "thick" description of virtual communities for researchers. However, it is thought that these classifications will evolve over time as new needs and wants in 
the cyberspace are developed. In other words, there will be new forms of virtual communities in the future. Therefore the developments in this area should be closely followed.

\section{Virtual Consumer Communities}

Virtual communities of consumption are defined as "affiliative groups whose online interactions are based upon shared enthusiasm for, and knowledge of, a specific consumption activity or related group of activities" (Kozinets, 1999: 54). Virtual communities develop into an influential source of knowledge about the product or service as members join and contribute to discussions (Kim and Jin, 2006). From that point of view, virtual communities provide a new media for marketers not only to interact with consumers but also to create customer satisfaction. In addition, virtual consumer communities may be essential in increasing intangible and emotional attributes associated with the product and brand, and therefore they help to create brand equity. They are also an interesting tool for market segmentation and brand awareness (Flavian and Guinaliu, 2005).

A brand community is a relational structure created around the admiration for a brand (Muniz and O'Guinn, 2001). It is a set of individuals who voluntarily relate to each other for their interest in some brand or product (Flavian and Guinaliu, 2005). Brand-based virtual communities have several opportunities (McWilliam, 2000). In virtual brand communities, consumers are allowed access to free content and are able to form relationships with other consumers including the brand managers. Therefore, a link between the brand and the consumers evolves. Also, in brand-based virtual communities marketers are able to research consumer perceptions about the brand. However, in developing brand-based virtual communities the group of members, not the product, must be the object of attention (Bagozzi and Dholakia, 2002). Thus, marketers should focus on providing the "right environment" for members to come together and become active members (Kim and Jin, 2006).

Apart from communities that form specifically around a particular brand (either for or against the brand), the other virtual communities also contribute to the marketers. Bulletin boards and chat rooms that are devoted to special interest topics contain much information on consumer behavior. There are chat rooms that cover specific topic such as beer, wine, games, collecting, alternative medicines etc., and many others based on demographic segmentation variables (Catterall and Maclaran, 2001).

Marketing managers must consider the strategic implications of the existence of different types of both virtual community and real life community participation in order to be effective in the virtual environment (Kozinets, 1999). Within that scope, considering the value of the virtual community, marketers should consider that the virtual community consumers

-are more active and discerning;

- are less accessible to one-on-one processes; and

- provide a wealth of valuable cultural information (Evans, et al., 2001).

Studies reported in the literature were done to understand and profile virtual communities. One approach providing detailed and interpretive insights about virtual communities has been through cyber ethnographic research (Hair and Clark, 2007). 


\section{ETHNOGRAPHY AND CYBER ETHNOGRAPHIC RESEARCH}

Ethnography is a qualitative research method that provides a detailed description of a specific culture and society (Agafonoff, 2006). The origins of ethnography go back to the 1920s. It was first described by the anthropologist Bronislaw Malinowski in his book "Argonouts of the Western Pacific" published in 1922 (Harvey and Myers, 1995). Malinowski (1922) suggested that societies could only be understood by studying the context that they were in. This is the process in which the researchers actively learn the local language and live in a society for at least one year as a part of it (Elliot and Elliot, 2003).

Ethnography attempts to explicate structured patterns of actions that are cultural and/or social rather than merely cognitive, behavioral or affective (Arnould, 1998).

In order to develop insight about virtual communities, cyber ethnography has emerged as a methodology for the internet only within the past decade as a significant research method. It is also referred to as online ethnography or nethnography (Catterall and Maclaran, 2001). It is defined by Kozinets (1998: 366) as "a new qualitative research methodology that adapts ethnographic research techniques to study cultures and communities that are emerging through computer-mediated communications."

There are basically six steps followed in conducting cyber ethnographic research (Kozinets, 2002; Catterall and Maclaran, 2001):

1. Cultural Entrée: The first step in cultural entrée is the identification of the suitable online communities. There are five basic criteria in deciding which virtual community to choose. These are (Kozinets, 2002):

a. The chosen virtual community should have a most focused segment related to the research question.

b. The traffic in the community should be substantial and the number of postings should be high.

c. The virtual community should have large numbers of discrete message posters.

d. It should contain detailed and rich data.

e. The member contact related with the research subject should be interactive.

The researcher should be familiar with the characteristics of the virtual community. This requires a form of nonparticipant observation which is defined as "lurking" (Catterall and Maclaran, 2001). The aim of lurking is not only to learn about the virtual community but also to earn a place in the community. By lurking the researcher can identify a strategy to gain entry. Since members do not respond to requests for help, the researcher can find clues through one-to-one personal interactions in chat rooms.

2. Data Collection and Analysis: In cyber ethnographic research, the data collection process should continue until no new insights are generated. There are two sources of data collection. First, one copies the data directly from the communications among the virtual community 
members, and second one inscribes the data through the researcher's own observations within the virtual community (Kozinets, 2002). A major disadvantage of copying data directly from the interaction in a virtual community is quantity; there may be over 100 postings a day. In that case, the researcher has two options: to restrict the period covered or to follow only certain conversations or specific themes (Catterall and Maclaran, 2001). In analyzing the data collected, the researcher should distinguish between tourists, minglers, devotees and insiders (Kozinets, 2002, Kozinets, 1999; Langer and Beckman, 2005). Tourists have a superficial or passing interest in the virtual community and do not have a strong social tie to other members. Minglers have strong ties to the community but do not have much interest in the consumption activity. In contrast, devotees have a strong interest in consumption activity but have little contact with the other community members. And the last group that should be considered is insiders who have both a high involvement with the consumption activity and strong social ties, and so they are long-standing and referenced members. Devotees and insiders are important segments in marketing research because they represent actively involved, enthusiastic and sophisticated consumer groups (Kozinets, 2002). Another important point in data collection is the lack of paralinguistic cues (Catterall and Maclaran, 2001). Hence the control of the researcher diminishes. However online communication includes some non-verbal cues like emoticons (smiling or frowning faces) and the use of capitals or exclamation marks to emphasize emotions. The researcher should consider these cues in the data collection and interpretation stages. Cyber ethnographic research should be thought of as a multi-method approach including ethnographic content analysis, historical analysis, semiotic analysis, and document analysis.

3. Trustworthy Interpretation: There are two important points that should be considered while interpreting the data collected in cyber ethnographic research. The first point is concerned with the structure of the virtual world where identities are created, developed and discarded (Fox and Roberts, 1999). Thus the characteristics of the participants are often unknown and there is a possibility that the same participant may be interviewed more than once inadvertently (Catterall and Maclaran, 2001). The second point is concerned with the structure of the cyber ethnographic research. When interpreting data, the researcher should always remember that this research is content based. The data analyzed is "the content of a virtual community's communicative acts rather than the complete set of observed acts of consumers in a particular community" (Kozinets, 2002). And because a text-based data is used, the researcher should be careful in interpreting the data. In addition to these two above-mentioned critical points, it is important for the researcher to build trust within the community so that more accurate information can be gathered.

4. Ethics: Arnould (1998) determined that in the ethnographic research there are ethical concerns arising due the structure of the research. At first, the ethnographic research is up close and personal, because ethnography is concerned with explaining relationships or social events through their connections with other events (Wallman, 1997). Second, the nature of ethnographic research is socialization with a vengeance. Third, the ethnographic research is a procession research unlike the temporally limited experiments and surveys. Fourth, the ethnographic research requires emotional involvement and role-playing. And fifth, the ethnographic research exposes the life-worlds and life-projects of the participants (Arnould, 1998: 73). In relation to all these reasons, the researcher needs an ethical guideline to follow 
in conducting ethnographic research. Ethical concerns are important for cyber ethnographic researchers because online interactions are both private and public and the distinctions between the two are blurred. Hair and Clark (2007) describe five ethical dilemmas in cyber ethnographic research: (1) the meaning of being "ethical", (2) ethical philosophy, (3) codes of ethics-deontology, (4) outcome and use of research-teleology and utilitarianism, and (5) differing approaches between "management" researchers and social scientists. Kozinets (2002: 65) identified the code of ethics for cyber ethnographic research as below:

- The virtual community should be fully informed about the presence, affiliations and intentions of the researcher.

- The confidentiality and the anonymity of the participants should be ensured.

- The researcher should seek and incorporate feedback from members of the virtual community.

- The researcher should obtain permission of the participants to use the specific postings.

5. Member Checks: Member checking means presenting the final research report to the participants in order to solicit their comments (Arnould and Wallendorf, 1994; Kozinets, 2002). Member checking procedures allow the researcher to check the interpretation of the data with the virtual community members (Catterall and Maclaran, 2001). This procedure has four advantages (Kozinets, 2002): First, the participants can provide additional data and specific insights. Second, the errors or misunderstandings can be eliminated. Third, the contentious ethical concerns are ameliorated. And fourth, an ongoing relationship between the members of the virtual community and the researcher can be created.

6. Cultural Exit: After the ethnographic research is concluded, the researcher should exit from the society. In traditional ethnographic research it is easy to exit. But in cyber ethnographic research it is difficult for the researcher to withdraw due to the ongoing "telepresence" in the virtual world (Catterall and Maclaran, 2001). The term "telepresence" is used to describe the extent to which people feel their existence in the virtual space (Shih, 1998). In other words, the researcher and the accessibility of the community continue to exist in the virtual world. This can provide an opportunity for some marketing problems that require a continuing monitoring of the consumer group evolution.

In the literature, cyber ethnographic research is a newly emerging tool. It has been used since 1999 and few research studies conducted by using cyber ethnographic research exist. For this study, 12 research studies were selected and examined.

The aim of the studies was to better understand the virtual communities in terms of members' connectedness, power relations, online experiences, supplied marketing information, cross-cultural ambivalence, consumption cultures and customer empowerment. In general, it was seen that cyber ethnographic research was used to meet various objectives, to interpret different characteristics of virtual communities, to generate valuable insights, and, to come to_conclusions. However, the studies did not follow the standard stages of cyber ethnographic research and did not mention the stages. 
In the entry stage, the web sites and newsgroups related to the research subject were examined and the virtual communities were chosen through the criteria mentioned above.

The data was collected generally for 12-to18-month periods except one; Kozinets (2002) collected data during 33 months. To download posting for a long period provides huge amounts of data -hundreds of messages. Therefore, the researcher should be sensitive in analyzing that amount of data. Additional data adds value; however, the researcher should carefully evaluate the contributions of each.

In these studies, to collect data, participant observation and non-participant observation -lurking were used. Some studies mention the data collection stage in details, but some studies did not include as much information. Likewise, some of the researchers used other data collection techniques in addition to observation. Maulana and Eckhardt (2007) combined three data gathering techniques in cyber ethnographic research -- online interviews, diary analysis and observation of the web site usage, and behavior in order to examine the web site connectedness. They interviewed seven respondents in depth and analyzed the data gathered from 12 respondents in the diary study. They claimed that using diary analysis helped the credibility of the experience-based data since the diaries were believable representations of the reality.

Moreover, in their study about brand community and customer empowerment, Cova and Pace (2006) examined the "My Nutella the Community" and executed off-line interviews with two members of Ferrero's management team, Internet and Multimedia Manager and Director for Ferrero Italy Communication. In addition, the researchers realized off-line discussions with Nutella consumers at a "Nutella Party." Nyguyen et al. (2006) and Ward (1999) also used off-line communications and interviews with members.

In fact the contributions of off-line communications should be examined in cyber ethnographic research. Although the virtual community must be perceived as related to the physical world, the cyber ethnographic research aims to understand the existence of communities in the cyberspace. Within that scope, off-line communications and interviews should be evaluated as providing a richness to the conclusions but should not be perceived as a part of cyber ethnographic research.

There is an argument in the literature about the ethics in cyber ethnographic research. The public openness and wide access of the virtual communities cause researchers to discuss the privacy of the members. That is, some of the researchers accept the virtual community as a public communication while some accept it as a personal communication. In their study, Langer and Beckman (2005) did not introduce themselves to the community while they participated actively in the community. This is mainly because the research was about a sensitive topic. The authors specified this as follows (Langer and Beckman 2005: 197):

Based on the experience of the total lack of responses in recruitment attempts on internet message boards (IMBs) in the previously mentioned study and based on the fact that the IMB is regarded as a public communication media, 
it was decided not to inform contributors to this IMB about the identity of the analyst. No member checks were made, as participation in the IMB does not require formal relationship. Nor have authors of entries quoted in the study been informed or asked for permission to use direct quotations. In fact, many of the names that contributors used (often pseudonyms, such as "Sad(ie)," "The fat role," "The dissatisfied" or "Angry Woman") have been displayed in the study...

It should be also noted that, in the study executed by Sandlin (2007), the researcher chose to become a participant observer but the virtual community was not informed about the research.

Fox and Roberts (1999) had a different approach to the ethics in the cyber ethnographic research. The authors had several ethical concerns: first, the possibility of observer bias and consequent loss of validity; second, the basic ethical principle that the researchers should not come to harm as a consequence of their research; and third, a respect for the subjects' privacy and dignity. Therefore, one of the researchers became an active member and informed the virtual community about his identity, while the other became a passive member, did not introduce himself and observed the communications among the members. That approach enabled the researchers to evaluate the research environment and to supervise the fieldwork.

Generally, in the majority of the studies, the member check and the cultural exit stages were not mentioned. In the studies in which permission was not obtained from the members, the member check stage was omitted.

Table 1

Applications of Cyber Ethnographic Research in Literature

\begin{tabular}{|c|c|c|c|c|c|c|}
\hline $\begin{array}{l}\text { Author, } \\
\text { Year }\end{array}$ & $\begin{array}{l}\text { Subject of the } \\
\text { Study }\end{array}$ & Entrée & Data Collection & Interpretation & Ethics & $\begin{array}{l}\text { Member } \\
\text { Checks }\end{array}$ \\
\hline $\begin{array}{l}\text { Hewer and } \\
\text { Brownline, } \\
2007\end{array}$ & $\begin{array}{l}\text { Consumption } \\
\text { cultures }\end{array}$ & $\begin{array}{l}\text { Virtual } \\
\text { communities of car } \\
\text { consumption } \\
\text { Four virtual } \\
\text { communities were } \\
\text { chosen }\end{array}$ & $\begin{array}{l}\text { Non-participant } \\
\text { observation }\end{array}$ & $\begin{array}{l}\text { Historical data } \\
\text { was loaded }\end{array}$ & No mention & $\begin{array}{l}\text { No member } \\
\text { check }\end{array}$ \\
\hline $\begin{array}{l}\text { Maulana } \\
\text { and } \\
\text { Eckhardt, } \\
2007\end{array}$ & $\begin{array}{l}\text { Web site } \\
\text { connectedness }\end{array}$ & $\begin{array}{l}\text { Respondents were } \\
\text { recruited from } \\
\text { various mailing } \\
\text { lists }\end{array}$ & $\begin{array}{l}\text { Three methods } \\
\text { used: } \\
\text {-Online } \\
\text { interview } \\
\text {-Diary analysis } \\
\text {-Observation }\end{array}$ & $\begin{array}{l}\text { Data classified } \\
\text { Projective } \\
\text { technique in } \\
\text { interviews } \\
\text { Content } \\
\text { Analysis }\end{array}$ & No mention & No mention \\
\hline
\end{tabular}


Table 1 (continued)

\begin{tabular}{|c|c|c|c|c|c|c|}
\hline $\begin{array}{l}\text { Author, } \\
\text { Year }\end{array}$ & $\begin{array}{l}\text { Subject of the } \\
\text { Study }\end{array}$ & Entrée & Data Collection & Interpretation & Ethics & $\begin{array}{l}\text { Member } \\
\text { Checks }\end{array}$ \\
\hline $\begin{array}{l}\text { Sandlin, } \\
2007\end{array}$ & $\begin{array}{l}\text { Cyber } \\
\text { ethnographic } \\
\text { research in } \\
\text { consumer } \\
\text { education }\end{array}$ & $\begin{array}{l}\text { Readers of } \\
\text { Budget Line: The } \\
\text { discussion boards } \\
\text { "Critical fan" }\end{array}$ & $\begin{array}{l}\text { Participant } \\
\text { observation } \\
\text { Discussions } \\
\text { monitored } \\
\text { Reflective field } \\
\text { notes } \\
\text { Researcher's } \\
\text { memos } \\
\text { Feb.2003- Sept. } \\
2004\end{array}$ & $\begin{array}{l}\text { Data classified } \\
\text { Constant } \\
\text { comparative } \\
\text { technique }\end{array}$ & $\begin{array}{l}\text { No } \\
\text { identification } \\
\text { Virtual } \\
\text { community } \\
\text { members } \\
\text { were not } \\
\text { informed } \\
\text { about the } \\
\text { research }\end{array}$ & $\begin{array}{l}\text { No member } \\
\text { check }\end{array}$ \\
\hline $\begin{array}{l}\text { Nguyen, } \\
\text { Torlina, } \\
\text { Peszynski } \\
\text { and Corbitt, } \\
2006\end{array}$ & $\begin{array}{l}\text { Power relations } \\
\text { in virtual } \\
\text { communities }\end{array}$ & $\begin{array}{l}\text { Two virtual } \\
\text { communities were } \\
\text { chosen }\end{array}$ & $\begin{array}{l}\text { Observation } \\
\text { Off-line } \\
\text { communications } \\
\text { Collection } \\
\text { of notes and } \\
\text { messages }\end{array}$ & No mention & No mention & No mention \\
\hline $\begin{array}{l}\text { Cova and } \\
\text { Pace, } 2006\end{array}$ & $\begin{array}{l}\text { Improve } \\
\text { collective } \\
\text { customer } \\
\text { empowerment } \\
\text { theory }\end{array}$ & $\begin{array}{l}\text { Brand community } \\
\text { My Nutella The } \\
\text { Community was } \\
\text { chosen }\end{array}$ & $\begin{array}{l}\text { My Nutella the } \\
\text { Community } \\
\text { Participant } \\
\text { observation } \\
\text { Non-participant } \\
\text { observation } \\
\text { Off-line } \\
\text { interview }\end{array}$ & $\begin{array}{l}\text { Data classified } \\
\text { Content } \\
\text { Analysis }\end{array}$ & No mention & No mention \\
\hline $\begin{array}{l}\text { Langer and } \\
\text { Beckman, } \\
2005\end{array}$ & $\begin{array}{l}\text { Application of } \\
\text { nethnography to } \\
\text { sensitive areas }\end{array}$ & $\begin{array}{l}\text { Two web sites } \\
\text { were selected }\end{array}$ & $\begin{array}{l}\text { Health } \\
\text { information web } \\
\text { site } \\
\text { Womens' web } \\
\text { site } \\
\text { Jan.2001 - May } \\
2002 \\
\text { Non-participant } \\
\text { observation }\end{array}$ & $\begin{array}{l}\text { Data coded } \\
\text { Qualitative } \\
\text { Analysis }\end{array}$ & $\begin{array}{l}\text { No } \\
\text { identification } \\
\text { Virtual } \\
\text { community } \\
\text { members } \\
\text { were not } \\
\text { informed } \\
\text { about the } \\
\text { research }\end{array}$ & $\begin{array}{l}\text { No member } \\
\text { check }\end{array}$ \\
\hline $\begin{array}{l}\text { Nelson } \\
\text { and Otnes, } \\
2005\end{array}$ & $\begin{array}{l}\text { Construct of } \\
\text { cross-cultural } \\
\text { ambivalence }\end{array}$ & $\begin{array}{l}\text { Three virtual } \\
\text { communities on } \\
\text { cross-cultural } \\
\text { weddings }\end{array}$ & $\begin{array}{l}\text { Participant } \\
\text { observation } \\
\text { Non- participant } \\
\text { observation } \\
400 \text { postings } \\
\text { from } 16 \\
\text { countries } \\
\text { Aug.2000- Jul. } \\
2001\end{array}$ & $\begin{array}{l}\text { Archived } \\
\text { messages } \\
\text { Data coded } \\
\text { Constant } \\
\text { comparative } \\
\text { technique }\end{array}$ & No mention & No mention \\
\hline
\end{tabular}


Table 1 (continued)

\begin{tabular}{|c|c|c|c|c|c|c|}
\hline $\begin{array}{l}\text { Author, } \\
\text { Year }\end{array}$ & $\begin{array}{l}\text { Subject of the } \\
\text { Study }\end{array}$ & Entrée & Data Collection & Interpretation & Ethics & $\begin{array}{l}\text { Member } \\
\text { Checks }\end{array}$ \\
\hline $\begin{array}{l}\text { Kozinets, } \\
2002\end{array}$ & $\begin{array}{l}\text { Application of } \\
\text { nethnography }\end{array}$ & $\begin{array}{l}\text { Overview of } \\
\text { newsgroups }\end{array}$ & $\begin{array}{l}\text { Online coffee } \\
\text { community } \\
33 \text { months } \\
\text { Participant } \\
\text { observation } \\
\text { Non-participant } \\
\text { observation }\end{array}$ & $\begin{array}{l}\text { Data classified } \\
\text { Content } \\
\text { Analysis }\end{array}$ & $\begin{array}{l}\text { Permission } \\
\text { taken from } \\
\text { the members }\end{array}$ & $\begin{array}{l}\text { with } 9 \\
\text { members }\end{array}$ \\
\hline $\begin{array}{l}\text { Maclaran } \\
\text { and } \\
\text { Catterall, } \\
2002\end{array}$ & Virtual worlds & $\begin{array}{l}\text { Overview of web } \\
\text { sites }\end{array}$ & $\begin{array}{l}\text { Megastore web } \\
\text { site } \\
\text { Participant } \\
\text { observation } \\
\text { Non-participant } \\
\text { observation } \\
\text { Opportunistic } \\
\text { approach }\end{array}$ & No mention & $\begin{array}{l}\text { Conducted } \\
\text { code of ethics }\end{array}$ & No mention \\
\hline $\begin{array}{l}\text { Fox and } \\
\text { Roberts, } \\
1999\end{array}$ & $\begin{array}{l}\text { Interaction } \\
\text { in virtual } \\
\text { communities }\end{array}$ & $\begin{array}{l}\text { Overview of web } \\
\text { sites } \\
\text { Participated as } \\
\text { active member }\end{array}$ & $\begin{array}{l}\text { Non-participant } \\
\text { observation } \\
\text { Participant } \\
\text { observation } \\
\text { Computer } \\
\text { generated } \\
\text { medical } \\
\text { community } \\
\text { Posted messages } \\
\text { Archive search } \\
12 \text { month period }\end{array}$ & Used NUD*IST & $\begin{array}{l}\text { Permission } \\
\text { taken }\end{array}$ & No mention \\
\hline Ward, 1999 & $\begin{array}{l}\text { Virtually new } \\
\text { community }\end{array}$ & $\begin{array}{l}\text { Two web sites } \\
\text { chosen }\end{array}$ & $\begin{array}{l}\text { Cybergirl and } \\
\text { WHOA } \\
\text { Non-participant } \\
\text { observation } \\
\text { Interview }\end{array}$ & $\begin{array}{l}\text { Content } \\
\text { analysis }\end{array}$ & No mention & No mention \\
\hline
\end{tabular}

\section{The Pros and Cons of Cyber Ethnographic Research}

Cyber ethnography is a stand-alone method of tracking marketing-related behavior of virtual communities (Kozinets, 2002). It provides valuable contributions for the marketing and e-commerce. It has several advantages as compared to the other research techniques. Those advantages arise as part of the ethnographic approach and as part of doing the research online. 
As part of the ethnographic approach, first of all, cyber ethnography is a method well suited to gaining insights about the virtual communities. Because the virtual communities have a cultural composition, cyber ethnographic research provides a deeper understanding of behavior, habits, needs and wants (Ward, 1999; Catterall and Maclaran, 2001). Also it is adaptable to a variety of circumstances due to its rich qualitative content and the open-endedness of its findings (Kozinets, 2002). Next, the participants take a more active role in the research process. The interactivity between the researcher and the participants provides the opportunity to gather subjective understandings of the participants and to forward the research (Ward, 1999). In addition, in cyber ethnographic research, the researcher can check the interpretation of the data with the virtual community members (Catterall and Maclaran, 2001; Kozinets, 2002). Through that the researcher gains specific insights, eliminates the misunderstandings, and develops an ongoing relationship. It has a dynamic structure as well as being flexible and adaptable to the interests and skills of the researcher (Kozinets, 2002).

Furthermore, there are specific advantages of cyber ethnographic research arising from doing the research online. First of all, executing the research in the cyberspace enables the researcher to examine different cultures. One important thing in that point is the knowledge about the other languages. This critical point can be overcome by studying with the researchers who have knowledge and experience related to those cultures. Through that, secondly, in the cyber ethnographic research the researchers have an opportunity to conduct cross-cultural studies. The information technologies connect the researchers to the cultures and communities. Hence, the researchers can reach a community having a different culture from theirs just by connecting to the internet. Moreover, the researchers can access the historical data, and thus can evaluate the past of the virtual community. This is important because that helps the researchers develop deeper understandings about the virtual social world. Next, it is less costly than personal interviews, focus groups and traditional ethnography (Kozinets 2002). In addition, researchers can directly copy the data required and, through that, save time in the research process (Catterall and Maclaran, 2001; Kozinets, 2002).

The cyber ethnographic research has some limitations as well as its opportunities. Within the traditional interview situation, the interviewer has the control over the process. But in cyber ethnographic research a dialogue emerges between the researcher and the participants, and therefore the control of the researcher diminishes (Ward, 1999). Since there is an online connection, the participant can terminate the interview at any time (Catterall and Maclaran, 2001). In addition, cyber ethnographic research is not so "closed" and therefore no definitive answer for the research question is produced. In other words, the research remains unfinished and reflexive (Ward, 1999). The interpretation of the data collected through cyber ethnographic research requires that the researchers have interpretive skills (Kozinets, 2002). Because there are huge amounts of data, to categorize them requires researcher sensitivity. However, the researchers have to imagine and create the link between the virtual existence and the physical existence. The approach in that point is that any individual in the virtual community must be perceived as being in a relationship with the wider physical world (Ward, 1999). And because in the virtual world identities are created, developed and discarded (Fox and Roberts, 1999), the identities of the participants are unknown and there is possibility that the same participant may be interviewed more than once unknowingly (Catterall and Maclaran, 2001). In cyber ethnographic research there is no "reality" upon which participants' representations might be based. That is, the community exists only in people's heads (Fox and Roberts, 1999). Lastly, in cyber ethnography the data is collected for the cyberspace and so there is a lack of paralinguistic cues (Catterall and Maclaran, 2001). 


\section{CONCLUSION}

The virtual communities are shaped by the developments in the communication and information technology and today constitute a new and emerging area. Cyberspace became a social space through the accelerated growth of the virtual communities. Most of the companies accept that building a strong web-community is an important marketing activity (Alper, 1998; Ward, 1999).

The members of virtual communities have more or less specific, complex and common goals, which they further by electronic communication (Geyer, 1996). The virtual communities, just like the traditional communities, have their own rules and norms. On that point, because of its natural cultural composition, ethnographic-based research produces useful determinations on virtual communities. Cyber ethnographic research is a flexible qualitative research including multiple data collection. It generates valuable information on the deeper roots of the behavior.

However, it is a new research method and the studies executed by the cyber ethnographic research date back only a decade in the literature. The process of the research was settled by Kozinets (2002) and developed through the various studies. But there are different approaches to the research processes of the studies. That is, there is not a standardized procedure followed but, rather, different applications. It is thought that conducting the research within a standard frame will improve that technique as a research tool.

The second important issue about the applications is the ethical principle. There is a debate over whether the communications in the virtual communities are personal or public communications. In addition, the mistrust and bias of the participants are discussed by the researchers. But the ethics constitutes an important part of the scientific approach. Therefore, a code of ethics should be considered in the studies. The approach of Fox and Roberts (1999) can create valuable conclusions for the researchers. In their research, one of the researchers became an active member and obtained permission, while the other became a passive member, did not introduce himself, and merely observed the communications. Through that, the researchers observed the virtual community as participant and non-participant observers simultaneously.

Lastly, in general, the studies did not mention the process of cyber ethnographic research in detail. In other words, the studies did not contain detailed information in relation to the stages of the research. It would be helpful to the other researchers who will use the research in future studies to give the clear frame of the process. Again this will contribute to the technique.

In general, cyber ethnographic research is a helpful research tool and it is thought that it will be used as an increasingly important research method in the future mainly because cyberspace has an accelerated development. As the information technologies spread all over the world, the communication will change its pace. Even now, millions of people all over the world have a virtual existence. The meaning of the community has changed within last 50 years. Internet creates and fulfills new needs and wants. Within that scope, it is thought that cyber ethnographic research will produce valuable information about the "lives" in cyberspace. 


\section{REFERENCES}

Agafonoff, N. (2006). “Adapting Ethnographic Research Methods to Ad Hoc Commercial Market Research," Qualitative Market Research: An International Journal, 9(2): 115-125.

Alper, A. (1998). “A Cyber-store-y,” Computerworld, 32(23): 18-19.

Armstrong, A. and Hagel, J. (1997). Net Gain: Expanding Markets through Virtual Communities. Boston: Harvard Business School Press.

Arnould, E.J. (1998). "Ethical Concerns in Participant Obseration/ Ethnography," Advances in Consumer Research, 25: 72-74.

Arnould, E.J. and Wallendorf, M. (1994). "Market-Oriented Ethnography: Interpretation Building and Marketing Strategy Formulation,” Journal of Marketing Research, 31: 484-505.

Catterall, M. and Maclaran, P. (2001). "Researching Consumers in Virtual Worlds: A Cyberspace Odyssey,” Journal of Consumer Behaviour, 1(3): 228-237.

Chase, N. (1998). “Multiple Nets, Integrated Image,” Quality, 37(6): 79-81.

Chiu, C.M., Meng-Hsiang, H., and Wang, E.T.G. (2006). "Understanding Knowledge Sharing in Virtual Communities: An Integration of Social Capital and Social Cognitive Theories," Decision Support Systems, 42: 1872-1888.

Cova, B. and Pace, S. (2006). "Brand Community of Convenience Products: New Forms of Customer Empowerment - The Case 'my Nutella The Community'," European Journal of Marketing, 9(10): 1087-1105.

Elliot, R. and Elliot N.J. (2003). "Using Ethnography in Strategic Consumer Research," Qualitative Market Research: An International Journal, 6(4): 215-223.

Evans, M., Wedande, G., Ralston, L., and van't Hul, S. (2001). "Consumer Interaction in the Virtual Era: Some Qualitative Insights," Qualitative Market Research: An International Journal, 4(3): 150159.

Flavian, C. and Guinaliu, M. (2005). "The Influence of Virtual Communities on Distribution Strategies in the Internet," International Journal of Retail and Distribution Management, 33(6): 405-425.

Fox, N. and Roberts, C. (1999). "GPs in Cyberspace: The Sociology of a 'Virtual Community'," The Sociological Review, 47(4): 643-671. 
Geyer, F. (1996). “Virtual Communities in Cyberspace,” Kybernetes, 25(4): 60-66.

Goulding, C. (2005). "Grounded Theory, Ethnography and Phenomenology: A Comparative Analysis of Three Qualitative Strategies for Marketing Research," European Journal of Marketing, 39(3/4): 294-308.

Hair, N. and Clark, M. (2007). "The Ethical Dilemmas and Challenges of Ethnographic Research in Electronic Communities,” International Journal of Market Research, 49(6): 781-800.

Harvey, L.J. and Myers, M.D. (1995). "Scholorship and Practice: The Contribution of Ethnographic Research Methods to Bridging The Gap," Information Technology and People, 8(3): 13-27.

Hewer, P. and Brownlie, D. (2007). "Cultures of Consumption of Car Aficionados," International Journal of Sociology and Social Policy, 27(3/4): 106-119.

Kanayama, T. (2003). "Ethnographic Research on the Experience of Japanese Elderly People Online," New Media and Society, 5(2): 267-288.

Kardaras, D., Karakostas, B., and Papathanassiou, E. (2003). “The Potential of Virtual Communities in the Insurance Industry in the UK and Greece," International Journal of Information Management, 23(1): 41-53.

Kim, H.S. and Jin, B. (2006). "Exploratory Study of Virtual Communities of Apparel Retailers," Journal of Fashion Marketing and Management, 10(1): 41-55.

Kozinets, R.V. (1998). "Ensouling Consumption: A Nethnographic Exploration of the Meaning of Boycotting Behavior," Advances in Consumer Research, 25: 475-480.

Kozinets, R.V. (2002). "The Field behind the Screen: Using Netnography for Marketing Research in Online Communities," Journal of Marketing Research, 39: 61-72.

Langer, R. and Beckman, S.C. (2005). "Sensitive Research Topic: Nethnography Revisited," Qualitative Market Research: An International Journal, 8(2): 189-203.

Lee, F.S.L., Vogel, D., and Limayem, M. (2003). "Virtual Community Informatics: A Review and Research Agenda," Journal of Information Technology Theory and Application, 5(1): 47-61.

Maclaran, P. and Catteral, M. (2002). "Researching the Social Web: Marketing Information from Virtual Communities," Marketing Intelligence and Planning, 20(6): 319-326. 
Maulana, A.E. and Eckhardt, G.M. (2007). "Just Friends, Good Acquaintances or Soul Mates? An Exploration of Web Site Connectedness," Qualitative Market Research: An International Journal, 10(3): 227-242.

Mead, G. H. (1993). “The Emergent Self,” in J. Farganis (ed.), Readings in Social Theory: 143-164. New York: McGraw-Hill.

Muniz, A. and O'Guinn, T. (1998). "Brand Community," Working Paper, University of Illinois at Urbana-Champaign, IL.

Nelson, M.R. and Othes, C.C. (2005). "Exploring Cross-Cultural Ambivalence: A Netnography of Intercultural Wedding Message Boards," Journal of Business Research, 58: 89-95.

Nguyen, L., Torlina, L., Peszynski, K., and Corbitt, B. (2006). "Power Relations in Virtual Communities: An Ethnographic Study,” Electronic Commerce Research, 6: 21-37.

Rheingold, H. (1994). The Virtual Community. London.

Sandlin, J.A. (2007). "Nethography as a Consumer Education Research Tool," International Journal of Consumer Studies, 31: 288-294.

Shih, C.F. (1998). "Conceptualizing Consumer Experiences in Cyberspace," European Journal of Marketing, 7(8): 655-663.

Talukder M. and Yeow, P.H.P. (2006). “A Study of Technical, Marketing and Cultural Differences Between Virtual Communities in Industrially Developing and Developed Countries," Asia Pacific Journal of Marketing and Logistics, 18(3): 184-200.

Walls, J. (1993). “Global Networking for Local Development,” in L. Harasim (ed.), Global Networks: 152-165. Cambridge, Mass: The MIT Press.

Ward, K. (1999). “Cyber-Ethnography and the Emergence of the Virtually New Community,” Journal of Information Technology, 14: 95-105

Wellman, B. (2005). "Community: From Neighborhood to Network," Communication of the ACM, 48(10): 53-55

Whitmore, S. (1999). “Are You Privy to the Private Net?” MC Technology Marketing Intelligence, 19(7): 54-56. 
Wilbur, S. (1997). “An Archaeology of Cyberspace: Virtuality, Community Identity,” in D. Porter (ed.), Internet Culture: 5-23. New York: Routledge.

Wilson, S.M. and Peterson, L.C. (2002). "The Anthropology of Online Communities," The Annual Review of Anthropology, 31: 449-467 